\title{
Polymorphism in Exon-1 of MSTN Gene in Boer and Bakerwal Goats and its Association with Growth Traits
}

\author{
Wani A. Ahad", Sajad A. Beigh, Mehraj uddin Reshi, Rumase A. Bhat, \\ Aadil Yousuf, John Mohmmad Wani, Mudasir Andrabi and Riaz A. Shah
}

Division of Animal Biotechnology, Faculty of Veterinary Sciences and Animal Husbandry, Sher-e-Kashmir University of Agricultural Sciences and Technology of Kashmir, Shuhama Alusteng, Ganderbal, 190006, J\&K, India

*Corresponding author

\section{A B S T R A C T}

Myostatin or growth and differentiation factor 8 (GDF8), is a skeletal muscle regulator factor that determines muscle mass in animals including human beings. Mutation in the myostatin gene sequence controls its regulating function and results in growth via hypertrophy of muscles. Mutation in myostatin gene has been found in various species of animals and has three exons and two introns in all species. Considering the MSTN gene as

Keywords

MSTN,

Polymorphism,

Boer, Bakerwal,

Growth traits,

Myostatin.

Article Info

Accepted:

26 August 2017

Available Online:

10 September 2017 a candidate gene for gene assisted selection for growth traits, the present study was aimed to study its polymorphism and its association in Boer and Bakerwal goats in Kashmir valley. We screened polymorphism of the myostatin gene in 600 goats from two goat populations (Boer and Bakerwal) and applied PCR and DNA sequencing analysis to reveal single nucleotide polymorphisms (g.368A >C (p.Lys to Thr). At g.368A >C locus, the frequencies of $\mathrm{g} .368 \mathrm{~A}$ allele were $0.70-0.80$, and the frequencies of $\mathrm{g} .368 \mathrm{C}$ allele were $0.20-0.30$ in Boer goats. And at g.368A $>$ C locus, the frequencies of g.368A allele were $0.60-0.80$, and the frequencies of g.368C allele were $0.20-0.40$ in Bakerwal goats. Compared to AC genotype, those with AA genotype had superior body weight in Boer goats (12 \& 14 months) (41.68 \pm 0.41 vs $43.21 \pm 0.31, P<0.05)(43.57 \pm 0.41$ vs 46.00 $\pm 0.05, P<0.05)$ respectively. In addition, the Boer goats (13 months) with AA genotype $(72.50 \pm 0.50 \mathrm{~cm})$ had greater body height than those with AC genotype $(70.37 \pm 0.26 \mathrm{~cm})$. Similarly, AA genotype in Bakerwal goats have high body weight than AC genotype (40.16 \pm 0.54 vs $42.75 \pm 0.25), P<0.01$ (12 months), body length (81.12 \pm 0.63 vs 86.00 $\pm 1.00), P<0.05$ (14 months) and chest circumference (86.42 \pm 0.61 vs $89.66 \pm 0.33$ ), $P<0.05$ (13 months) respectively. These SNPs would provide molecular genetic material for studying the meat performance of goats.

\section{Introduction}

Majority of the goat population is nondescript that is capable of producing very less meat and milk. With shrinking resources and increasing demand of goat meat and milk, there is urgent need to genetically improve and manage these animals through modern scientific tools to enhance their productivity. Although, there is a need to utilize betweenbreed genetic differences for higher yields, greater emphasis is required on improvement of adapted indigenous breeds/types because of valuable adaptive traits they have developed 
over long periods of time through natural selection. Breeding strategies for enhancing goat meat and milk production in the country is needed (Dekkers and Hospital, 2002). Advances in genomics and proteomics offer an opportunity to look at collective behavior of a large number of genes under a given situation. There is an urgent need to map the goat genome. Therefore there is a need to annotate the genes at the protein level by proteomic approaches.

Boer goat (Capra hircus) is considered to be one of the most important goat breeds for meat production. It has gained worldwide recognition for excellent body conformation, fast growing rate and good carcass quality. It has a strong impact on the meat goat industry globally (Schina 2009). Boer Goat is indigenous to South Africa and is dual purpose and claimed to bear all the attributes which a high yielding improved breed of goat should posses. It is also adapted to a wide range of climatic conditions and in addition, it produces on an average $2 \mathrm{kgs}$ of milk per day containing 7-9\% fat. The Boer goat has a birth weight of $2.4 \mathrm{kgs}$ weaning weight $35 \mathrm{kgs}$ and $115 \mathrm{~kg}$ adult weight in males. With the introduction of this goat in Kashmir, there would be boost to meat production in the valley. The Bakerwal breed of goat is a good meat purpose breed that attains a significant body mass under a low input production system. The sheep and goats constitute the main livestock wealth.

The huge Bakerwal goats fetch attractive prices on the festive occasion of eid when people purchase them for sacrificial purposes. Apart from obtaining meat from sheep and goats, the Bakerwals also obtain milk, hides and wool from them. The Bakerwal goats augment the meat production of the otherwise meat deficient state of $\mathrm{J} \& \mathrm{~K}$. Indeed, they are the real custodians of our livestock (Ahad et al., 2016).
Mutations within the GDF8 gene inactivate its expression or turn out a non-functional protein that results in dramatic muscularity and a "double-muscling" development in several species. Two traits, carcass quality and quantity are the most important factor in the meat industry. These traits have an effect on vital factors like genetics, climate, nutrition and so on. And presently much research is done to predict carcass traitsin livestock animasls. Among the factors that confirm the meat quality, genetic factors have a prominent role on meat quality (Kioumarsi et al., 2008). Trend is growing towards demand for lean meat with low levels of fat, that conformable with human health standards scale. Results development of breeding programs and genetic improvement of economic animals with higher production in last decades. At recent years, there has been a beautiful progress on quantities and genetics through mapping of the economic animals' genome and new opportunities are provided for increase meat production and market place for demand customers (Dekkers and Hospital, 2002). Numerous QTLs have been identified that influence muscle growth and carcass traits. At the current time few mutations in these QTLs are known and under survey. The mutation in myostatin gene reported that has been associated with increase in weight and carcass traits in many species (Masri et al., 2011). Mutated MSTN gene and inactive myostatin have a major association with growth rate and carcass traits. MSTN gene causes increase in muscle mass. Mutation in myostatin has a very important impact on carcass quality and reduces quantity of fat in the dead body. In animals with hypertrophy phenotype, fat quantity cuts down into 50 percent and muscle mass will increase 20 percent additionally connective tissues decrease in these animals thus delicate and delicious meat is created. The most determinants of quick growth in animals is the increase of vegetative cell growth and 
proliferation. Myostatin may be a negative protein that inhibits terminal differentiation of myoblasts and therefore the proliferation of myogenic cells (Thomas et al., 2000). The growth traits of animals are regulated by several genes and are of primary concern throughout breeding for determining the animal's economical price. Generally, distinguishing genetic markers for growth traits is the initial and significant condition to establish a marker-assisted selection system. The gene sequence and its variations are of prime importance in studying gene expression and function. Polymorphisms in MSTN gene were shown to possess a major difference in several goat breeds. It was reported that the TTTTA deletion in the MSTN gene had emerged in several species and may be distinctive for goats, compared with sheep, cattle, Buffalo, domestic yak, pigs, and humans (Hadjipavlou et al., 2008).

Many candidate genes have been detected in goats. However, few investigations have been carried out on the polymorphism of some genes involved in the control of productive traits. Candidate genes have an effect on the physiological pathway, metabolism and the expression of phenotypes. For growth traits, growth hormone $(G H)$, leptin $(L E P)$, insulin like growth factor I (IGF-I), growth hormone receptor $(G H R)$, caprine pituitary specific transcription factor-1 (POU1F1), caprine myostatin $(M S T N)$ and bone morphogenetic protein $(B M P)$ genes are necessary for bone formation, birth weight, weaning weight, body condition and muscle growth(Schina2009).

Myostatin/Growth differentiation factor (MSTN/GDF8) is a member of the transforming growth factor- $\beta$ (TGF- $\beta)$ superfamily. It is produced by skeletal muscle and acts as a negative regulator of muscle growth, which plays an essential role in the regulation of muscle growth and meat quality (Zhang et al., 2013). Myostatin and activin interact and activate a heterodimeric receptor complex with serine-threonine kinase activity, comprising a type II receptor, activin receptor 2 (ACVR2 and ACVR2B), and a type I receptor, active in receptor-like kinase 4 and 5 (ALK4 and ALK5). Myostatin signaling in myofibers is mediated by phosphorylation and nuclear translocation of transcription factors, and formation of heterodimers. Heterodimer complex binds to the promoters in the target genes \& forms a transcription repressor complex. Myostatin represses the levels of myogenic regulatory factors (MyoD, Myf4, Myf5 and myogenin) leading to the inhibition of myogenic differentiation. Myostatin inhibits myogenic differentiation factor (MyoD) activity and expression via $\mathrm{Smad} 3$ resulting the failure of the myoblasts to differentiate into myotubes (Figure 2).

The Caprine GDF8gene has 3 exons and 2 introns (Bellinge et al., 2005) (Figure 1). Mutations in the MSTN gene can inactivate its expression or produce a non-functional protein, which leads to dramatic muscularity and a "double-muscling" phenomenon in many species (Grisoliaet al., 2009). Mutations in sheep myostatin gene also has a significant role in muscular growth (Boman et al., 2009). As a consequence, the MSTN gene is primarily responsible for muscle development and could be a potential candidate gene for animal muscle growth. The single nucleotide polymorphisms (SNPs) with MSTN would provide molecular genetic material for studying the meat performance of goat and its further exploitation for "double muscling" phenomenon.

\section{Materials and Methods}

\section{Samples and DNA extraction}

Genomic DNA samples were obtained from 600 goats: Boer goat $(\mathrm{N}=300)$ and Bakerwal goat $(\mathrm{N}=300)$, which were both reared at 
Mountain Research Centre for Sheep and Goat (MRCSG) and Sheep Breeding Farm Banihal respectively. Blood samples were collected from goats in vacutainer tubes, homogenized and kept frozen once until needed for DNA extraction, which was performed by using Phenol-ChloroformProteinase-K Method (Sambrook and Russell, 2001). The selection of animals was based on age (12-14 months), based on their growth characteristics (Zhang et al., 2013). The growth traits of Boer and Bakerwal goats from the same farm were recorded for statistical analysis. The following traits were evaluated: body weight, body height, body length and chest circumference (12-14 months of age). Body weight (BW) was taken by using the Salter hanging spring type scale. Body height was taken between the most dorsal point of the withers and the ground level (Pesmen and Yardimci, 2008). A tailor's tape was used to determine; Body length (BL), measured from the anterior point of the shoulder joint to the posterior extremity of the pin bone (Katongole et al., 1996). Chest circumference was measured by taking the circumference of the chest using a tailor's tape calibrated in $\mathrm{cm}$, taken as the circumference of the body immediately behind the shoulder blades in a vertical plane, perpendicular to the long axis of the body (Pesmen and Yardimci, 2008).

\section{Primer synthesis and PCR}

After quantification and dilution of the DNA samples, the 492-bp fragment of exon-1 of caprine MSTN gene was amplified (Figure 3) by PCR using primer reported by $\mathrm{Li}$ et al., (2008) as shown in table 1. Each $25 \mu \mathrm{L}$ reaction contained $50 \mathrm{ng}$ of sample DNA, 0.4 $\mu \mathrm{M}$ of each primer, 1X PCR buffer $(10 \mathrm{mM}$ Tris- $\mathrm{HCl}, \mathrm{pH} 8.0,50 \mathrm{mMKCl}), 2.0 \mathrm{mM}$ $\mathrm{MgCl} 2,0.2 \mathrm{mM}$ of each $\mathrm{dNTP}$ and $1 \mathrm{U}$ of Taq DNA polymerase (Invitrogen). Amplification reactions were carried out in a thermocycler (Applied BioSystem), with 5 min denaturation at $95^{\circ} \mathrm{C}, 35$ cycles of $94^{\circ} \mathrm{C}$ for $1 \mathrm{~min}, 59^{\circ} \mathrm{C}$ for $1 \mathrm{~min}$ and a $72^{\circ} \mathrm{C}$ extension for $1 \mathrm{~min}$, and a final extension at $72^{\circ} \mathrm{C}$ for $4 \mathrm{~min}$.

\section{Sequencing and statistical analysis}

The PCR amplified products were sequenced at Macrogen Inc. Korea, with an automated sequencer (Applied Biosystems) (Figure 6). The resulting sequences were aligned using the BioEdit program (BioEdit v5.0.9) and the obtained consensus sequences were used to compare it with GenBank caprine sequence using the BLAST algorithm, to find out the polymorphism with respect to $368 \mathrm{~A}>\mathrm{C}$ of MSTN gene and the genotypes of two breeds were recorded accordingly. An association study was carried out for the SNP located in exon-1 of MSTN gene with goat growth traits. The data generated was subjected to Mann Whittney U test by using SPSS20.0 statistical software and significance was determined at $\mathrm{p}<0.05$ to estimate the association between different genotypes and growth traits.

\section{Results and Discussion}

\section{Analysis of sequencing results}

The PCR products of different genotypes were sequenced. We found single mutation located at 368A $>\mathrm{C}$ (Figures 4 and 5), by carrying out a BLAST search of goat MSTN gene sequences in GenBank sequence. The nucleotide sequences of exon-1 of the MSTN gene was deposited in GenBank under Accession No KU980201. The substitution $368 \mathrm{~A}>\mathrm{C}$, caused a variation of amino acid lysine to threonine. The following conclusions were demonstrated by Mann Whittney U test by using SPSS20.0 statistical software, and genotypic and allelic frequencies in the 2 different goat breeds was calculated. These genotypic results indicated 
that allele A was absolutely dominant in Boer goats and Bakerwal goats.

\section{Association of MSTN polymorphism with growth traits in Boer goats}

The mutation from A to $\mathrm{C}$ at position 368 in the exon 1 of MSTN gene results in substitution of lysine by threonine of the peptide chain encoded by MSTN gene, indicated as $368 \mathrm{~A}>\mathrm{C}$ polymorphism with two alleles, two genotypes were produced, AA and AC.The two different genotypes were then associated with growth traits. There was a significant difference in body weight Boer goats (12 \& 14 months) between AA and AC group $(\mathrm{P}<0.05)$, and also there was a significant difference in body height between AA and AC group $(\mathrm{P}<0.05)$ in case of 13 months goats.As from the above findings it was evident that AA genotype is associated with high body height of Boer goats (Table 2).

\section{Association of MSTN polymorphism with growth traits Bakerwal goats}

Like that of Boer breed, Bakerwalgoat were also grouped into three and two groups, according to their age and genotypes respectively. The association was studied between genotypes and growth traits. There was a significant difference in body weight Bakerwal goats (12 months) between AA and AC group $(\mathrm{P}<0.01)$ and also there was a significant difference in body length in Bakerwal goats (13 months) between AA and AC group $(\mathrm{P}<0.01)$ and significant difference in chest circumference between $\mathrm{AA}$ and $\mathrm{AC}$ group $(\mathrm{P}<0.05)$ (Table 3$)$.

Boer and Bakerwal populations at 368A>C loci had moderate genetic diversity. At g.368A $>C$ locus, the frequencies of g.368A allele were in the range of $0.70-0.80$, and the frequencies of g.368C allele were in the range of $\quad 0.20-0.30$ in case of Boer goats. Frequencies of alleles found in this study for Boer goats were same to the previously reported frequencies (An et al., 2011). And at g.368A >C locus, the frequencies of g.368A allele were $0.60-0.80$, and the frequencies of g.368C allele were $0.20-0.40$ in Bakerwal goats. However no such type of studies has been done in case of Bakerwal goats.

The genotype frequencies in Boer goatsfor $\mathrm{AA}$ and $\mathrm{AC}$ were found to be in the range of 0.70-0.80 and 0.20-0.30(An et al., 2011), which were similar to the genotype frequencies found inBakerwal goats.No homozygotes $\mathrm{CC}$ were found in the population.

There is a factor that could contribute to this, is sampling effect because the sample sizes were relatively small (Moreau et al., 1998; An et al., 2010). The findings were also reported by Hadjipavlou et al., (2008) and (Boman and Vage, 2009) in Charollais sheep and in two Norwegian sheep breeds. Also, findings were also reported by Esmailizadeh et al., (2008) and Gill et al., (2009) in Bos Taurus.

Compared to AC genotype, those with AA genotype had superior body weight in Boer goats (12 and 14 months) (41.68 \pm 0.41 vs $43.21 \pm 0.31, P<0.05)(43.57 \pm 0.41$ vs 46.00 $\pm 0.05, P<0.05)$ respectively.

In addition, the Boer goats (13 months) with AA genotype $(72.50 \pm 0.50 \mathrm{~cm})$ had greater body height than those with AC genotype (70.37 $\pm 0.26 \mathrm{~cm})$.

Similarly, AA genotype in Bakerwal goats have high body weight ( $40.16 \pm 0.54$ vs 42.75 $\pm 0.25), P<0.01$ (12 months), body length (81.12 \pm 0.63 vs $86.00 \pm 1.00), P<0.05$ (14 months) and chest circumference (86.42 \pm 0.61 vs $89.66 \pm 0.33$ ),$P<0.05$ (13 months) respectively. 
Fig.1 Structure of MSTN gene

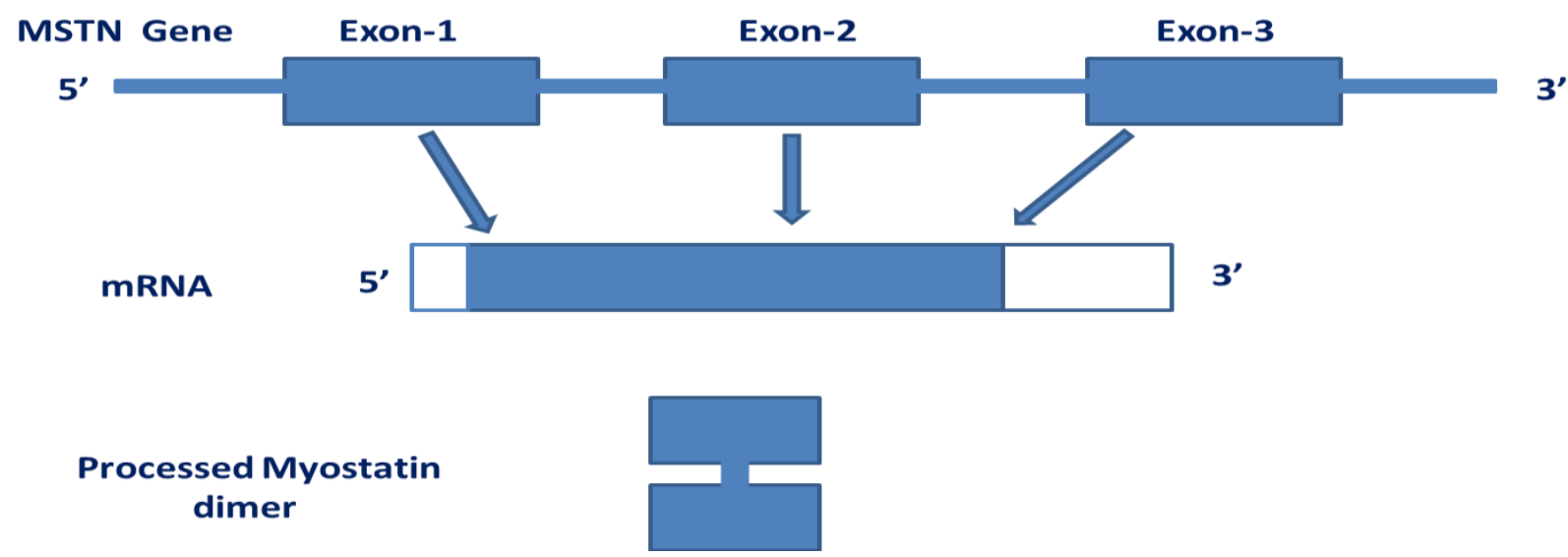

Fig.2 Physiological Action of Myostatin

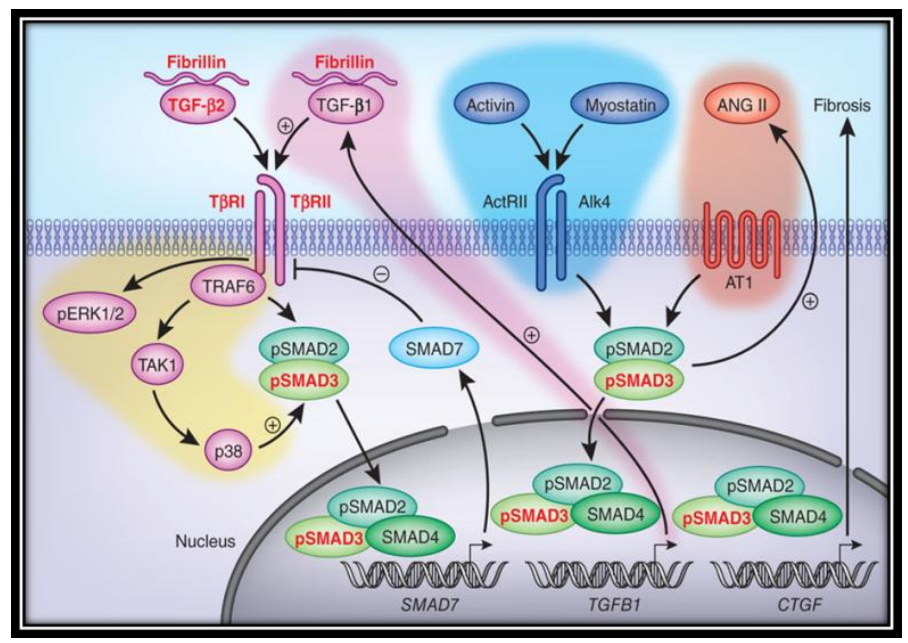

Fig.3 Gel electrophoresis picture of amplified fragment of MSTN gene in Boer (a) and Bakerwal (b) goat Size: 492bp

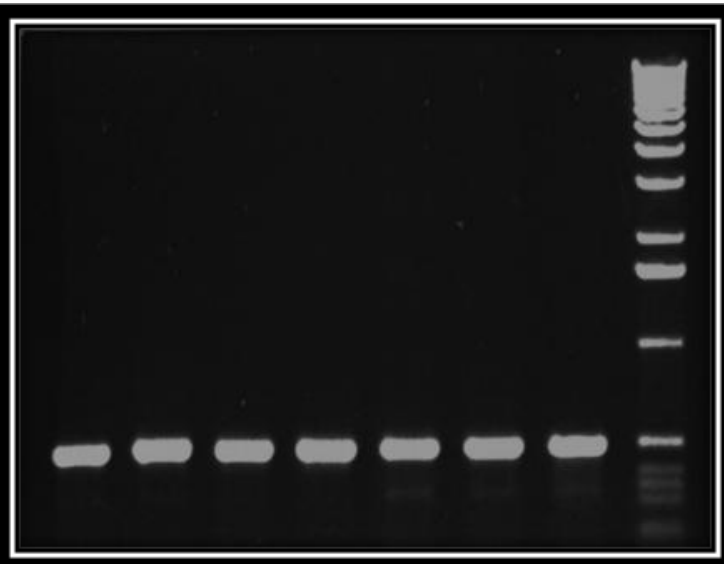

(a)

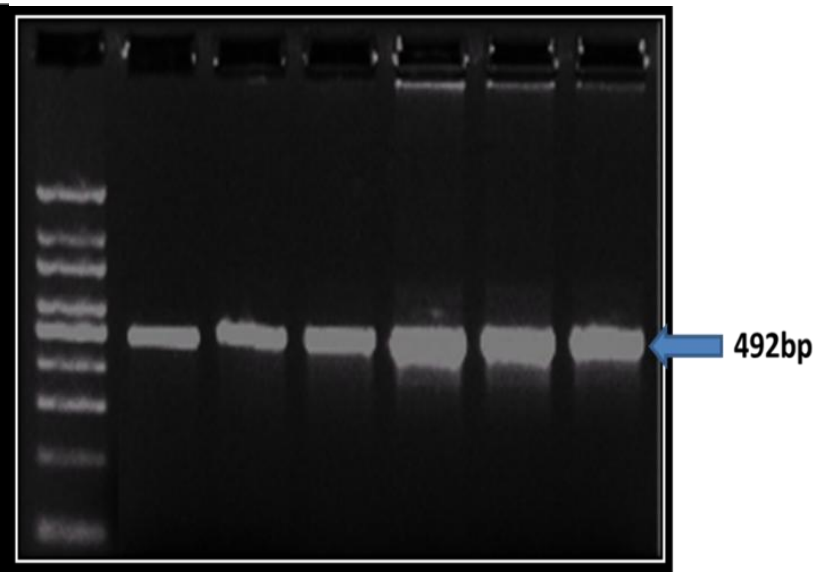

(b) 
Fig.4 \& 5 Chromatograms showing mutation site in Exon-1 of MSTN Gene in Boer and Bakerwal goats

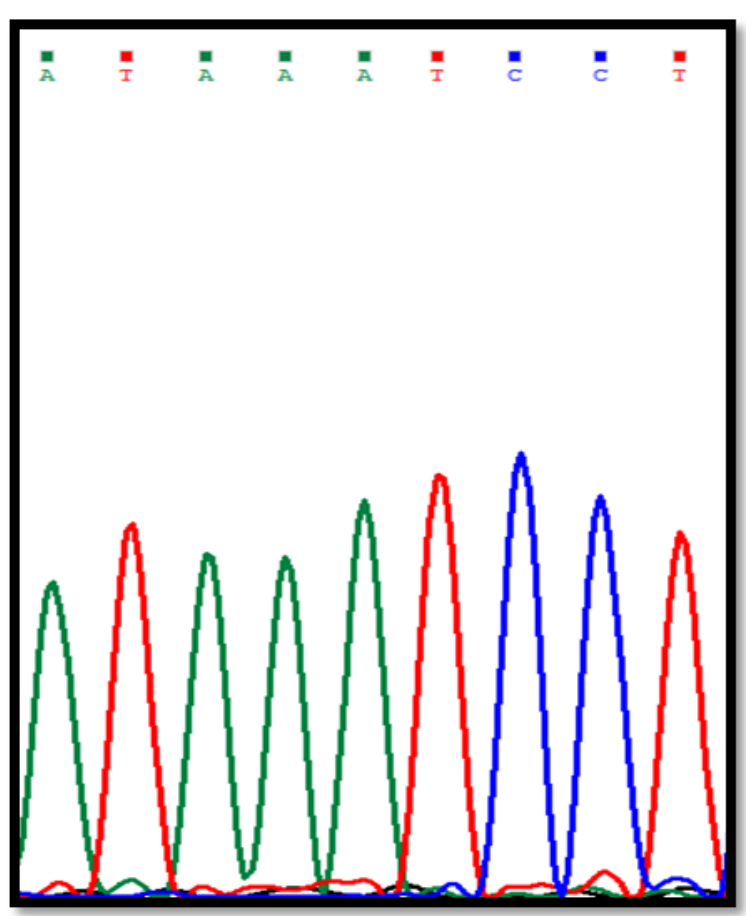

(4) AA Genotype

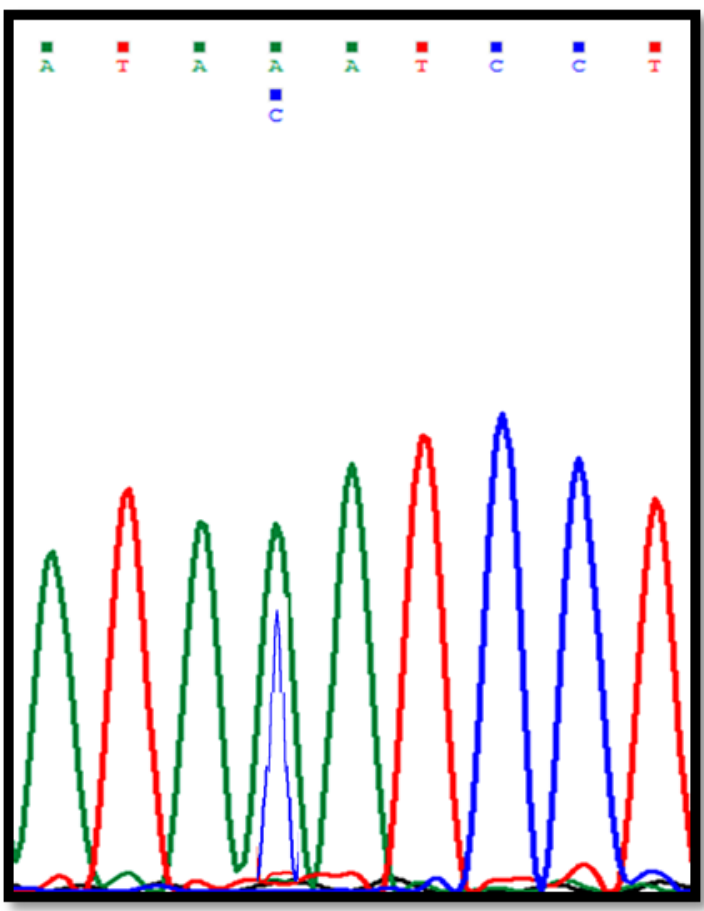

(5) AC Genotype

Fig.6 Sequencing result of Exon-1 of myostatin gene

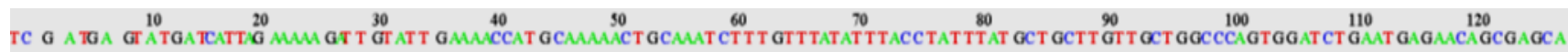

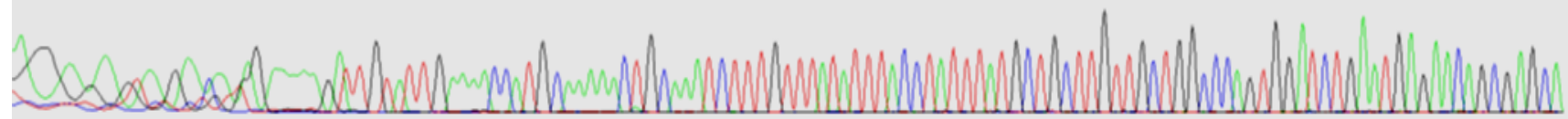

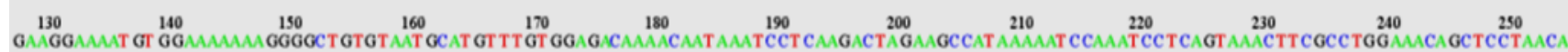

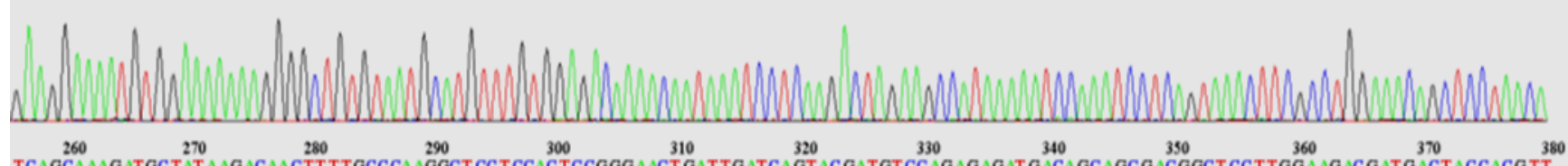

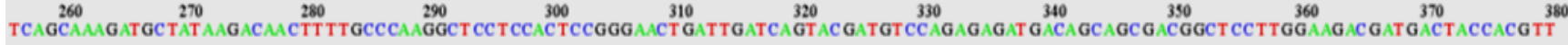

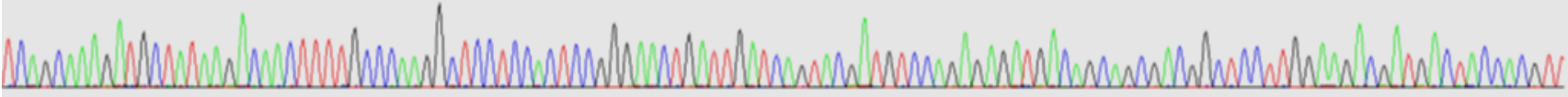

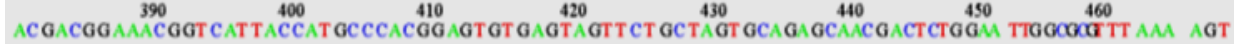


Table.1 Sequence of the forward $(\mathrm{F})$ and reverse $(\mathrm{R})$ primers used for the amplification of goat myostatin gene exon-1

Exon

Primers (5' to 3')

Reference

\begin{tabular}{lll}
\hline 1 & F-TGGCGTTACTCAAAAGCAAA & Li et al., 2008 \\
& R-AACAGCAGTCAGCAGAGTCG & \\
\hline
\end{tabular}

Table.2 Least square means $( \pm \mathrm{SE})$ analysis between genotype of polymorphism in the MSTN gene and growth traits of Boer goat

\begin{tabular}{|c|c|c|c|c|c|c|}
\hline \multicolumn{7}{|c|}{$\begin{array}{l}\text { Breed/AgeGE GF Growth traits } \\
\text { BOERBody weight Body height Body length Chest }\end{array}$} \\
\hline $\begin{array}{c}12 \\
\text { months }\end{array}$ & $\begin{array}{l}\mathbf{A C} \\
\mathbf{A A} \\
\mathrm{P}\end{array}$ & $\begin{array}{l}30.0 \% \\
70.0 \%\end{array}$ & $\begin{array}{c}41.68 \pm 0.41^{\mathbf{A}} \\
43.21 \pm 0.31^{\mathbf{B}} \\
\mathrm{P}=0.03\end{array}$ & $\begin{array}{c}70.28 \pm 0.35 \\
71.33 \pm 0.33 \\
P=0.12\end{array}$ & $\begin{array}{c}79.42 \pm 0.36 \\
79.66 \pm 0.33 \\
P=0.71\end{array}$ & $\begin{array}{c}85.71 \pm 0.52 \\
88.00 \pm 0.57 \\
P=0.06\end{array}$ \\
\hline $\begin{array}{c}13 \\
\text { months }\end{array}$ & $\begin{array}{l}\mathbf{A C} \\
\mathbf{A A} \\
\mathrm{P}\end{array}$ & $\begin{array}{l}20.0 \% \\
80.0 \%\end{array}$ & $\begin{array}{c}43.31 \pm 0.17 \\
44.83 \pm 0.76 \\
P=0.08\end{array}$ & $\begin{array}{c}70.37 \pm 0.26^{\mathbf{A}} \\
72.50 \pm 0.50^{\mathbf{B}} \\
P=0.04\end{array}$ & $\begin{array}{c}79.50 \pm 0.18 \\
80.50 \pm 1.50 \\
P=0.66\end{array}$ & $\begin{array}{c}87.00 \pm 0.70 \\
88.50 \pm 0.50 \\
P=0.35\end{array}$ \\
\hline $\begin{array}{c}14 \\
\text { months }\end{array}$ & $\begin{array}{l}\mathbf{A C} \\
\mathbf{A A} \\
\mathrm{P}\end{array}$ & $\begin{array}{l}30.0 \% \\
70.0 \%\end{array}$ & $\begin{array}{c}43.57 \pm 0.41^{\mathbf{A}} \\
46.00 \pm 0.05^{\mathrm{B}} \\
\mathrm{P}=0.02\end{array}$ & $\begin{array}{c}71.00 \pm 0.37 \\
72.33 \pm 0.33 \\
P=0.08\end{array}$ & $\begin{array}{c}80.00 \pm 0.53 \\
81.33 \pm 0.66 \\
P=0.18\end{array}$ & $\begin{array}{c}87.85 \pm 0.67 \\
88.66 \pm 0.88 \\
P=0.48\end{array}$ \\
\hline
\end{tabular}

$\mathrm{GE}=$ Genotype; GF = Genotype Frequency; $\mathrm{SE}=$ standard error of the mean. Means followed by capital superscript letters differ significantly at $\mathrm{P}<0.05$.

Table.3 Least square means $( \pm \mathrm{SE})$ analysis between genotype of polymorphism in the MSTN gene and growth traits of Bakerwal goat

Breed/AgeGE GF Growth traits

BAKERWAL Body weight Body height Body length Chest

\begin{tabular}{clccccc}
\multicolumn{5}{c}{ Circumference } \\
\hline 12 & AC & $40.0 \%$ & $40.16 \pm 0.54^{\mathbf{a}}$ & $70.66 \pm 0.49$ & $79.16 \pm 0.30$ & $85.50 \pm 0.42$ \\
months & AA & $60.0 \%$ & $42.75 \pm 0.25^{\mathbf{b}}$ & $71.50 \pm 0.64$ & $81.25 \pm 0.85$ & $87.50 \pm 0.64$ \\
& $\mathrm{P}$ & & $\mathrm{P}=0.01$ & $\mathrm{P}=0.38$ & $\mathrm{P}=0.07$ & $\mathrm{P}=0.05$ \\
& & & & & & \\
$\mathbf{1 3}$ & AC & $30.0 \%$ & $44.44 \pm 0.49$ & $71.14 \pm 0.40$ & $79.42 \pm 0.20^{\mathbf{a}}$ & $86.42 \pm 0.61^{\mathbf{A}}$ \\
months & AA & $70.0 \%$ & $46.41 \pm 0.77$ & $72.66 \pm 1.20$ & $83.00 \pm 1.15^{\mathbf{b}}$ & $89.66 \pm 0.33^{\mathbf{B}}$ \\
& $\mathrm{P}$ & & $\mathrm{P}=0.11$ & $\mathrm{P}=0.23$ & $\mathrm{P}=0.01$ & $\mathrm{P}=0.02$ \\
& & & & & & \\
$\mathbf{1 4}$ & AC & $20.0 \%$ & $45.71 \pm 0.55$ & $74.00 \pm 0.46$ & $81.12 \pm 0.63^{\mathbf{A}}$ & $88.00 \pm 0.65$ \\
months & AA & $80.0 \%$ & $48.25 \pm 0.25$ & $76.00 \pm 1.00$ & $86.00 \pm 1.00^{\mathbf{B}}$ & $91.50 \pm 1.50$ \\
& $\mathrm{P}$ & & $\mathrm{P}=0.05$ & $\mathrm{P}=0.14$ & $\mathrm{P}=0.04$ & $\mathrm{P}=0.11$
\end{tabular}

$\mathrm{GE}=$ Genotype $; \mathrm{GF}=$ Genotype Frequency; $\mathrm{SE}=$ standard error of the mean. Means followed by capital superscript letters differ significantly at $\mathrm{P}<0.05$. Means followed by small case superscript letters differ significantly at $\mathrm{P}<$ 0.01 . 
Hence, the physiological functions and the results obtained in our investigation suggest that the myostatin gene play a significant role in expression of growth traits in goats. It could be interpreted that the myostatin gene may be a major gene affecting the goat economic traits. The polymorphic site can be a molecular marker-assisted selection program for body weight. The results of relationship between the different genotypes and growth traits showed that the 368A>C locus mutation was significantly associated with the growth traits $P<0.05$. The missense mutation (p.Lys to Thr) has effects on the myostatin protein structure and on the biological function of the myostatin protein (Grobet et al., 1997, 1998). Hadjipavlou et al., (2008) found that two SNPs in the myostatin gene have a significant association with the muscle depth of Charollais sheep. Two different mutations in the myostatin coding region in two Norwegian sheep breeds are associated with carcass conformation (Boman and Vage, 2009). In pigs, mutations identified in noncoding regulatory regions affect the level of myostatingene expression and are associated with muscle mass and other carcass traits (Stinckens et al., 2008). Esmailizadeh et al., (2008) found a SNP in the myostatingene affecting growth, carcass and beef quality traits of Bostaurus. In cattle breeds, an 11-bp deletion in the coding sequence of the myostatin gene determines increased skeletal muscle mass and the produced phenotype is known as doublemuscling (Gill et al., 2009). This supports that further investigation of the myostatin variation in different goat breeds is needed. In goats number of myostatin mutations of different phenotypic expressions has been described in variety of breeds (Javanmard et al., 2010), but there is scarcity of reports on the association analysis of SNPs with growth traits. The biochemical and physiological functions and the results obtained in our study indicate that the myostatin gene may play significant role in affecting the economic traits in goats. The polymorphisms we have identified in exon-1 of the myostatin gene (368A $>C$ locus) could be potential genetic markers for growth traits in goats.

The obtained results indicate that the exon-1 of myostatin gene evaluated in the present study is polymorphic in boer and bakerwal goats and can be noticed for the marker assisted selection, especially to improve the body weight. Further characterization of mutations responsible for muscle hypertrophy in goats will not only allow producers to incorporate gene-assisted selection (GAS) into their breeding programs, but it will also contribute to our basic understanding of muscle formation.

\section{Acknowledgements}

The facilities and support of the Division of Animal Biotechnology, Faculty of Veterinary Sciences and Animal Husbandry, Sher-eKashmir University of Agricultural Sciences \& Technology of Kashmir, J\&K, India and the help provided during sample collection from the Mountain Research Centre for Sheep and Goat (MRCSG) Shuhama Alusteng, J\&K, India are acknowledged.

\section{Conflict of interest}

The authors declare that they have no conflict of interest.

\section{References}

Ahad, W.A., et al., 2016. Sequence Characterization of Coding Regions of the Myostatin Gene (GDF8) from Bakerwal Goats (Capra hircus) and Comparison with the Sheep (Ovisaries) Sequence. Open Journal of Animal Sciences, 6, 157-162. http://dx.doi.org/10.4236/ojas.2016.63020 An, X.P., Han D., Hou, J.X., Li, G., Wang, 
Y.N., Li, L., Zhu, G.Q., Wang, J.G., Song, Y.X., Cao, B.Y. 2010. Polymorphism of exon 2 of $F S H \beta$ gene and its relationship withreproduction performance in two goat breeds. Agricultural Sciences in China9:880-886.

An, X.P., Hou, J.X., Wang, L.X., Li G., Wang, J.G., Song, Y.X.,Zhou, G.Q., Han, D., Ling, L., Cao, B.Y. 2010. Novel polymorphisms of the growth hormone gene and theireffect on growth traits in Chinese goats. Meat Science86:758-763.

An, X.P., Wang, W.G., Hou, J.X., Zhao, H.B., Bai, L., Li, G., Wang, L.X., Liu, X.Q., Xiao, W.P., Song, X.Y. and Cao, B.Y. 2011. Polymorphism identification in the goat MSTN gene and association analysis with growth traits. Czech Journal of Animal Science56 (12):529-535.

Bellinge, R.H.S., Liberles, D.A., Iaschi, S.P.A. and O'brien, P.A. 2005. Myostatin and its implications on animal breeding.Animal Genetics36:1-6.

Boman, I.A., Klemetsdal, G., Blichfeldt, T., Nafstad, O. and Vage, D.I. 2009. A frame shift mutation in the coding region of the myostatin gene (MSTN) affects carcass conformation and fatness in Norwegian White Sheep (Ovisaries). Animal Genetics40:418-422.

Boman, I.A., Vage, D.I. 2009. An insertion in the codingregion of the myostatin $(M S T N)$ gene affects carcass conformation and fatness in the Norwegian Spaelsau (Ovisaries). BMC Research Notes 2:98.

Casas, E., Bennett, G.L., Smith, T.P.L. and Cundiff, L.V. 2004. Association of myostatin on early calf mortality, growth, and carcass composition traits in crossbred cattle. Journal of Animal Science 82:2913-2918.

Dekkers, J.C.M., and Hospital, F. 2002. The use of molecular genetics in the improvement of agricultural populations.Nature Reviews Genetics3:22-32.

Esmailizadeh, A.K., Bottema, C.D.K., Sellick, G.S., Verbyla, A.P., Morris, C.A., Cullen, N.G. \& Pitchford, W.S. 2008.Effects of the myostatin F94Lsubstitution on beef traits. Journal of Animal Science86:10381046.

Gill, J.L., Bishop, S.C., Macorquodale, C., Williams, J.L. and Wiener, P. 2009. Associations between the 11-bp deletion in the myostatin gene and carcass quality in Angus-sired cattle. Animal Genetics40:97-100.

Grisolia, A.B., D'Angelo, G.T., Porto Neto, L.R. and Siqueira, F. 2009. Myostatin (GDF8) single nucleotide polymorphisms in Nellore cattle. Genetics and Molecular Research8:822-830.

Grobet, L., Martin, L.J.R., Poncelet, D., Pirottin, D., Brouwers, B., Riquet, J., Schoeberlein, A., Dunner, S., Menissier, F., Massabanda, J., Fries, R., Hanset, R. \& Georges, M. 1997. A deletion in the bovine myostatin gene causes the double muscled phenotype in cattle. Nature Genetics 17:71-74.

Grobet, L., Pirottin, D., Farnir, F., Poncelet, D., Royo, L.J., Brouwers, B., Christians, E., Desmecht, D., Kahn, R., \& Georges, M. 2003.Modulating skeletal musclemass by postnatal, muscle-specific inactivation of the myostatin gene. Genesis35:227-238.

Grobet, L., Poncelet, D., Royo, L.J., Brouwers, B., Pirottin, D., Michaux, C., Menissier, F., Zanotti, M., Dunner, S.,Georges, M. 1998. Molecular definition of an allelic series of mutations disrupting the myostatin function and causing doublemuscling in cattle. Mammalian Genome9:210-213.

Hadjipavlou, G., Matika, O., Clop, A. and Bishop, S.C. 2008. Two single nucleotide polymorphisms in the myostatin $(G D F 8)$ gene have significant association with muscle depth of commercial Charollais sheep. Animal Genetics39:346-353.

Javanmard, A., Panandam, J.M., Sugnaseelan, S. and Yusoff, K. 2010. Allele frequencies at six candidate genes associated with growth and carcass quality traits in the Boer goats. African Journal of Biotechnology9:7236-7238.

Katongole, B. D., B. Sebolai and M. J. 
Madimabe. 1996. Morphological characterization of the Tswana goat. In: Proceedings of the Third Biennial 37 Conference on the African Small Ruminant Research Network UIAC, Kampala, and Uganda1994:43-47.

Kioumarsi, H., Jafari, khorshidi, K., Zahedifar, M., Seidavi, A.R., Yahaya, Z.S., Rahman, W.A. and Mirhosseini, S.Z. 2008. Estimation of relationships between components of carcass quality and quantity in Taleshi lambs. Asia Journal of Animal and Veterinary Advances3:337343.

Li, X.L., Liu, Z.Z., Zhou, R.Y. and Zhang, G.R. 2008.Deletion of TTTTA in 5'UTR of goat MSTNgene and its distribution in different population groups and genetic effect on bodyweight at different ages.Frontiers of Agriculture in China 2:109.

Masri, A.Y., Lambe, N.R., Macfarlane, J.M., Brotherstone, S.H. and Bunger, L. 2011. Evaluating the effects of a single copy of a mutation in the myostatin gene (c.*1232 GNA) on carcass traits in crossbred lambs. Meat Science87:412-418.

McPherron, A.C., and Lee, S.J. 1997. Double muscling in cattle due to mutations in the myostatin gene. Proceedings of National Academy of Sciences 23:12457-12461.

Pesmen, G., and Yardimci, M. 2008. Estimating the live weight using some body measurements in Saanen goats.Archivazootechnica11:30-40.

Sambrook, J., and Russell, D. W. 2001.
Molecular Cloning: A laboratory manual. $3^{\text {rd }}$ edition. Volume 1. Cold Spring Harbor Laboratory press, New York, USA.

Schina, 2009. The Important Candidate Genes in Goats - A Review. Walailak $J$ Sci\&Tech 6(1):17-36

Stinckens, A., Bijttebier, J., Luyten, T., Van Den Maagdenberg, K., Harmegnies, N., DeSmet, S., Georges, M. \& Buys, N. 2005. Detection of polymorphisms in themyostatin gene in Belgian Pietrain pigs. Communications in Agricultural and Applied Biological Sciences70:37-41.

Stinckens, A., Luyten, T., Bijttebier, J., Van den Maagdenberg, K., Dieltiens, D., Janssens, S., De Smet, S., Georges, M. \& Buys, N. 2008. Characterization of the complete porcine MSTN gene and expression levels in pig breeds differing in muscularity. Animal Genetics39:586-596.

Thomas, M., Langley, B., Berry, C., Sharma, M., Kirk, S., Bass, J. \&Kambadur, R. 2000.Myostatin, a negative regulator of muscle growth, functions by inhibiting myoblast proliferation. The Journal of Biological Chemistry 275:40235-40243.

Zhang, Z.J., Ling, Y.H., Wang, L.J., Hang, Y.F., Guo, X.F., Zhang, Y.H., Ding, J.P. and Zhang, X.R. 2013. Polymorphisms of the myostatin gene $(M S T N)$ and its relationship with growth traits in goat breeds. Genetics and Molecular Research 12(2):965-971.

\section{How to cite this article:}

Wani A. Ahad, Sajad A. Beigh, Mehraj uddin Reshi, Rumase A. Bhat, Aadil Yousuf, John Mohmmad Wani, Mudasir Andrabi and Riaz A. Shah. 2017. Polymorphism in Exon-1 of MSTN Gene in Boer and Bakerwal Goats and its Association with Growth Traits. Int.J.Curr.Microbiol.App.Sci. 6(9): 2629-2639. doi: https://doi.org/10.20546/ijcmas.2017.609.324 